\title{
ORIGINAL ARTICLE Parenting a child with autism
}

\author{
Criando filho com autismo \\ Márcia Cristina Maciel de Aguiar \\ http:///orcid.org/0000-0001-7797-4530 \\ Milena Pereira Pondé \\ hitp:///rcid.org/0000-0002-1222-5487
}

\section{Keywords}

Autism spectrum disorder, parents, mental health.

\begin{abstract}
Objective: This study analyzes subjective aspects associated with parents' perception of the changes that have affected their lives since the birth of their child with autism spectrum disorder (ASD). Methods: A qualitative study, using a narrative approach. Semi-structured interviews were conducted with 7 fathers and 16 mothers of children with ASD enrolled in a special needs school in Salvador, Bahia, Brazil. The interviews were transcribed, analytical categories were defined, and data interpreted. Results: Five categories were identified: "Emotional and Health-Related Effects", "Effects on Daily/Professional and Academic Life", "Effects on Marital and/or Affective/Sexual Life", "Effects on Social Life", "Adaptation Strategies". The analysis showed that, despite the impacts suffered, social support, professional help can facilitate parents' adjustment to life changes following the birth of a child with ASD. Conclusion: The physical and emotional demands of living with and parenting a child with ASD are enormous, include changes in social roles and in couples' social and affective/sexual lives, highlighting the need for parents to receive support from healthcare professionals, particularly mental health professionals. Care strategies need to be implemented for parents, in addition to the healthcare provided to their children, in order to improve the comprehensive care given to the child with ASD.
\end{abstract}

\section{RESUMO}

Objetivo: Este estudo buscou analisar os aspectos subjetivos associados à percepção dos pais sobre as mudanças ocorridas em suas vidas após o nascimento de seu filho com transtorno do espectro autista (TEA). Métodos: Estudo qualitativo, com abordagem metodológica de narrativa. Foram feitas entrevistas semiestruturadas com 7 pais e 16 mães de crianças com TEA em escola especial, Salvador-Bahia. As entrevistas foram transcritas, as categorias de análise, elaboradas e os dados, interpretados. Resultados: Foram identificadas cinco categorias: "impacto emocional e na saúde", "impacto na vida diária/profissional e acadêmica", "impacto na vida do casal e/ou afetiva/sexual", "impacto na vida social" e "estratégias de adaptação". A análise revelou que, apesar dos impactos sofridos, apoio social e ajuda profissional podem facilitar uma adaptação às mudanças na vida dos pais, a partir do nascimento do filho com TEA. Conclusão: Conviver e ser mãe ou pai de criança com TEA produz grande demanda

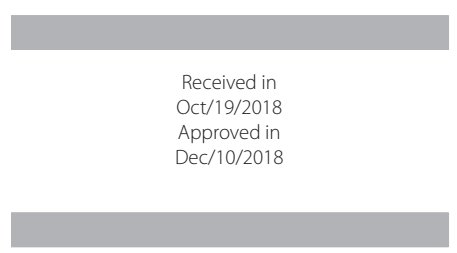

DOI: $10.1590 / 0047-2085000000223$

Address for correspondence: Márcia de Aguiar

Av. Dom João VI, 275, Brotas 40290-000 - Salvador, BA, Brasil

E-mail:mcrisdeaguiar@yahoo.com.br

1 Bahia State University. Bahia School of Medicine and Public Health. Laboratory for Research in Autism (LABIRINTO), Salvador, BA, Brazil. 2 Bahia School of Medicine and Public Health. Multidisciplinary Laboratory for Research in Autism (LABIRINTO), Salvador, BA, Brazil. 


\section{Palavras-chave}

Transtorno do espectro

autista, pais, saúde mental. física e emocional, mudança de papéis sociais, da vida social e da vida do casal e/ou afetiva/ sexual, o que demonstra necessidade de atenção aos pais por profissionais de saúde, especialmente os da saúde mental. Estratégias de cuidado precisam ser implantadas para os genitores, paralelamente à assistência à saúde dos seus filhos, buscando melhorar a atenção integral à criança.

\section{INTRODUCTION}

Autism spectrum disorder (ASD) is characterized by stereotypical behavior and restricted interests, impaired reciprocal social interaction and verbal and non-verbal communication skills' ${ }^{1}$. Hyperactivity, aggressive behavior towards themselves or others, intellectual disability, sensory alterations and sleep disorders are common associated conditions, which in turn, may worsen the prognosis of ASD $^{2}$.

The biomedical definition of Autism Spectrum disorder does not include all social aspects of the condition; however, an understanding of the emotional suffering must take into consideration the senses that manifest in the body, in the emotions, in the family and in the social context in general ${ }^{3}$. Thus, in the autism field, it is important to pay attention to the impact on the parents since their child's diagnosis and through the daily life with them.

Due to the clinical manifestations of ASD, the presence of an individual with this condition in the family negatively affects family functioning and the emotional well-being and social activities of family members ${ }^{4}$. Raising a child with ASD can be a crushing experience for the parents, which can lead to decreased efficacy, increased stress and both mental and physical health issues ${ }^{4,5}$.

Having a child with autism can generate insecurity in the parents ${ }^{5}$ and emotional symptoms such as anxiety and depression $^{6-8}$. Social support ${ }^{9}$ may help parents adapt to the reality of dealing with an autistic child. Since parents can adapt, this study sought to analyze subjective aspects associated with parents' perception of the changes that have affected their lives since the birth of their child with autism spectrum disorder.

\section{METHODS}

This qualitative study used a narrative approach. Parents of children attending a special needs school for individuals with ASD in the city of Salvador, Bahia, Brazil were approached and invited to participate. This was a convenience sample, the size of which was established when data saturation was reached. Semi-structured interviews designed to collect data regarding the experiences of parenting a child with ASD and a field diary containing the investigator's observations were analyzed. Interviews were recorded in the school grounds between July and November 2015 and accurately transcri- bed to a computer without grammatical correction. Seven fathers and sixteen mothers participated. Six key questions comprised the interview script. This paper analyzes responses to the question: "How is your life and that of your family with your autistic child"?

The procedure used to code the narratives generated from the interviews sought to relate fragments from the narratives with key ideas referred to as categories, as proposed by Gibbs ${ }^{10}$. Value was given not only to the content of the narratives that referred to the interviewer's questions but also to information related to the general idea of the changes that had occurred in parents' lives after the birth of their autistic children ${ }^{11}$. Following systematic reading of all the interviews, the categories were created, and the content of the narratives was grouped together, as appropriate, into these categories. The fragments from the narratives were marked in each interview and correlated with the categories. Fragments were identified as $M$ or $F$ (mother or father) plus a number, e.g. M11, F5. In the analysis, the content of the narratives was correlated with participant observation data, as recorded in the field diary, and with the reference literature ${ }^{10,12}$. Finally, a flowchart summarizing the analysis was constructed (Figure 1).

The internal review board of the Bahia School of Medicine and Public Health's approved the study protocol on July 13, 2015 under reference 1.146.792, CAAE 44094515.9.0000.5544 in accordance with the National Health Council's Resolution $466 / 12^{13}$. Participants were provided with information on the study and signed an informed consent form prior to enrollment.

\section{RESULTS}

The sample consisted of seven fathers and sixteen mothers, including three couples. The mean age of the fathers was 37 years; all were married; 43\% were university educated, while $28 \%$ had some high school education; and $85 \%$ were employed, with a mean family income of 3.3 minimum salaries. The mothers' mean age was 34 years; $50 \%$ were married and $69 \%$ had at least high school education; 75\% did not work and the mean family income was 2.1 minimum salaries. About children with ASD: twenty-three, nineteen boys and four girls, including three pairs of siblings. Mean age was 6.7 years.

From the analysis of the narrative fragments that indicated how the birth of their autistic child had affected the lives of 
the parents and family, five categories were identified: 1) "Emotional and Health-Related Effects"; 2) "Effects on Daily/ Professional and Academic Life"; 3) "Effects on Marital and/ or Affective/Sexual Life"; 4) "Effects on Social Life"; and 5) "Adaptation Strategies" (presented together with the other categories).

\section{Emotional and health-related effects}

M8, who has a 4-year old son, reported that when she learned that her son had ASD, she "couldn't breathe despite all the air in the world". "I just cried and cried, and couldn't see beyond the horizon. I imagined that he would be unable to do anything. It was as if he had died". This statement indeed shows that this was the moment when the mother began the experience of grieving for the ideal child, the healthy child.

The narratives revealed sadness to the point of depression, with suicidal and homicidal ideation. Most parents, particularly the mothers, reported emotional and physical overload resulting from having to care for their autistic child, in addition to stress factors, with consequently insufficient time for self-care in general and health-related care in particular. Feelings of helplessness and of needing help were mentioned often, mainly by the mothers but also by a father, who was his child's principal caregiver. Some mothers reported anguish because their child was not accepted within the family.

As an adaptation strategy, time, for some, lessened their suffering. Their partner's support, the presence of the partner in the home, and psychiatric and psychological support helped diminish pain and depression. Information and acceptance helped some parents adapt by learning to live with the problem.

"My wife was depressed, [...], the psychologist told her to see a psychiatrist. She cried a lot, [...]. To me, it was a disappointment, sadness, [...], one is already bad enough, imagine two. [...] The worst is the emotional, it's not only about treating the child, you have to treat the parents so they learn how to deal with this difficulty". F3 (4-year-old daughter with autism and 2-year-old son with autism).

"I am overwhelmed, I wake up tired, with a headache, high blood pressure, [...]. I saw a psychiatrist and she told me to get psychotherapy, a lot of tension, the medication is not enough, we need to talk, [...]". F7 (main caretaker of 10-year-old son with autism).

"We're edgy; he is hyperactive; he climbs up there; he comes over here; he falls; he gets stressed; it's very difficult. [...]. I don't think I'm normal anymore; I forget things; his Dad does too [...]; it's like we're going to explode at any moment. There's no time when we can just vent, [...]. When he is asleep, I just pass out, [...]". M11 (6-year old son with autism).

"All I could think about was killing myself and killing her; I blamed her; I put my life on hold; I had no social life; I couldn't work; I had to move to another town; I was upset [... . The key is admitting the problem; if I had kept on denying it, I would be on medication to this day". M14 (8-year old daughter with autism).

\section{Effects on daily/professional and academic life}

Most of the mothers are the principal caregivers. They generally spend almost all their time taking care of their children, with no time for any other activities. Since they did not have anyone else to help with this care or did not trust anyone else to help, the mothers' daily routine, professional life and academic plans were greatly affected. Most stopped working and/or studying, sometimes completely changing their lives.

In an attempt to adapt, the minority of mothers who continued working needed to alter their working hours. The fathers, when present in the home and participating in their child's care, did so by adapting their work schedule to support the mothers, allowing them to participate in other activities and/or rest. Some mothers used strategies such as returning to previous projects and leisure activities.

"It's his mother who takes care of him; she doesn't work [...]. Previously, she took care of everything; then I changed my working hours. She gave up college, left her job [...]; । take him for therapy so that she can do her things; I think she was exhausted". F5 (7-year old son with autism).

"Caring for three exhausts me; I'm very tired [...]. When they go to sleep, I sweep the floor, wash the dishes; when they are awake I can't touch the stove. If there is anything cooking, they have no idea; they touch it; it's dangerous [...]. I sleep at midnight and wake up at $5 \mathrm{am}$. I make their food; wash the dishes; I do the rest when they give me time [...]". M5 (6-year old triplets, one girl and two boys with autism).

"I work at the Mayor's office, [...], they are flexible with my schedule, so I can work and take him to treatment. [...] His dad made an agreement at work so he can help [...], on the days that I work, he works from 4 to 10 pm". M12 (7-yearold son with autism).

\section{Effects on marital and/or affective/sexual life}

Having an autistic child changes a couple's relationship. Many participants reported that the child's presence hampered or sometimes completely obliterated marital life. Although they managed moments alone together, the couple's space was reduced. For some, having an autistic child contributed to a marital crisis or separation. Some gave up on having another child for fear of it having the same problem. Unmarried mothers reported difficulty dating because of their child's problem.

"I separated from my husband; I was living for my child; I forgot my husband [...]. After separating from him, I have only dated one person, but he didn't understand my son 
[...]. I don't want another child. I am scared it would be the same or even worse [...]". M2 (8-year old son with autism).

"After the diagnosis of autism, we devoted all our time to him, to his treatment. Then a crisis developed in our marriage". M16 (5-year old son with autism).

\section{Effects on social life}

All the narratives suggested that being the mother of an autistic child changes and sometimes destroys their social life. Mothers seldom go out without their children since they have no one to care for them. Some mothers reported that since their families did not accept their autistic child. Other mothers described their embarrassment and anguish at society's discrimination of their child.

As an adaptation strategy, when they go out with their autistic children, most avoid certain places. They may stop going to relatives' homes, often seeking social isolation in view of the exclusion resulting from their children's maladapted behavior. Some mothers, however, mentioned social support as an important source of support, generally provided by friends from their church, by old friends or by their own mothers.

"I seldom take him to relatives' homes. He touches everything. They keep telling him not to touch; leave that alone [...]. Outside it's the same. If he shouts in the street, everyone looks [...]. It's so embarrassing. On the bus, he went to grab a young man's hat. The man got up. That day, I cried. The bus was full, but nobody sat beside us. It was as if he was rotten". M1 (10-year old son with autism).
"I don't go out anymore, I know their behavior is not normal. [...] In my Family, there is a distance towards my children, I also distance myself". M6 (4-year-old daughter with autism and 2-year-old son with autism).

"Thanks to Jehovah, I have friends. Let me tell you, I have friends I'll never be able to repay, [...]. These friends of mine are brethren in my faith; they give me everything they are able to. So I had a lot of support and still continue to count on it today [...]. I think that was the only thing that kept me sane. I only didn't go mad because I have true friends". M5 (six-year old triplets, one girl and two boys, both autistic).

"[...] My mother stays with him, but she comes to my house. I don't let him go to anyone else's house". M13 (11year old autistic son).

\section{DISCUSSION}

Based on the findings of the present study, the flowchart in Figure 1 shows the impact of having an autistic child on parents' lives. Following the birth of an autistic child, parents experience a period of mourning for the ideal child, as well as a physical and emotional overload, a loss of roles and social life, and damage to the couple's relationship and/or affective/sexual life. Sadness and depression develop, together with possible suicidal and homicidal thoughts. When social support and professional help are available in addition to strategies such as seeking information, altering working hours, changing leisure activities, returning to old projects,

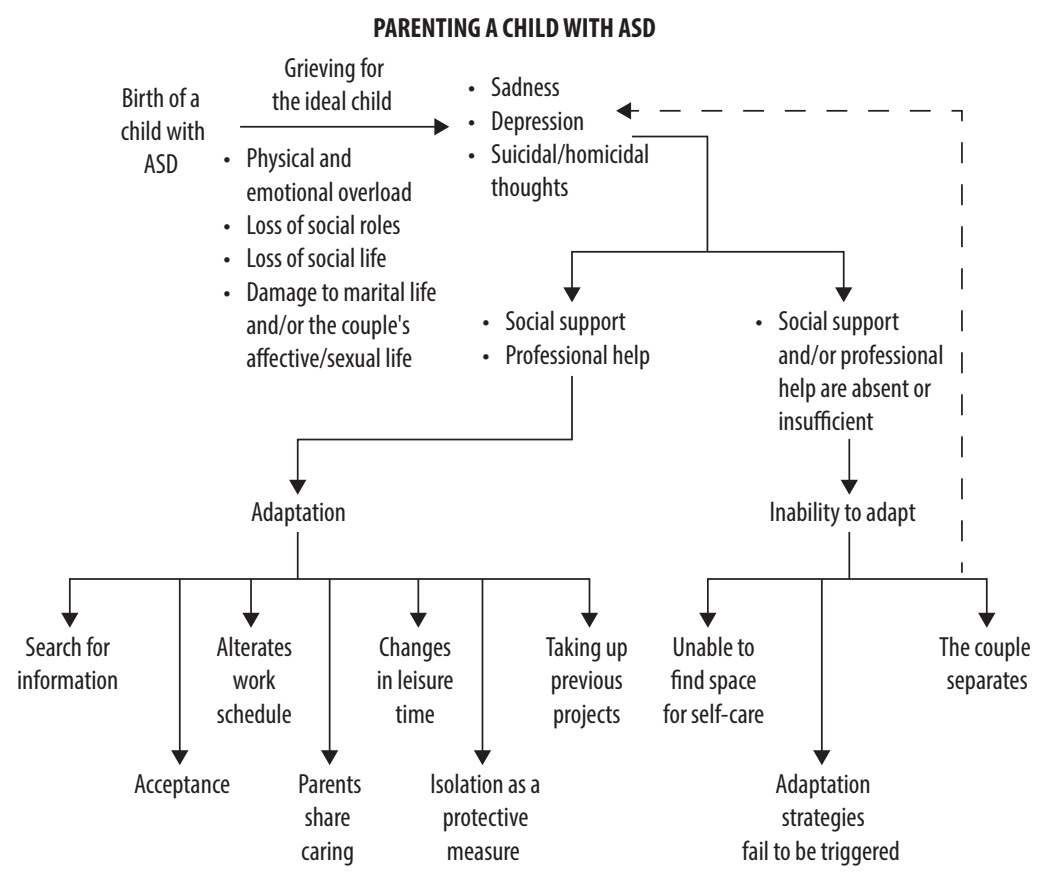

Figure 1. Flowchart depicting the impact of an autistic child on parents' lives. 
learning how to deal with the child, sharing care between parents, or even isolating themselves as a protective measure against discrimination, adaptation occurs gradually, lessening or obliterating sadness and/or depression. If social support and professional help are not available or are insufficient, if self-care is neglected and adaptation strategies are not implemented, the couple may separate, and sadness and depression may persist, constituting yet another health problem in the family.

In line with the findings of the present study, FaveroNunes and Santos ${ }^{4}$ also noted the parents' need to grieve for the "perfect" child when learning of their child's diagnosis of ASD. When the idealized child becomes a child with autism, the dreams and expectations that the parents project in relation to the child crumble ${ }^{14}$. This is understood as representing the first frustration experienced in the realm of parenting a child with ASD.

The narratives of parents of autistic children, particularly those of the mothers, reveal sadness and depression, together with suicidal and homicidal ideation. A high prevalence of stress, anxiety and depression in parents of autistic children has been previously reported ${ }^{9,15}$.

Most of the parents, particularly the mothers, reported an emotional and physical overload that hampered their ability to look after themselves in general and their health in particular. Favero-Nunes and Santos ${ }^{4}$ emphasized that as well as the mother's emotional overload resulting from having to care for an autistic child, there is the added burden of household chores to be taken care of. A systematic review reported that parenting an autistic child requires restructuring family arrangements, often generating emotional and physical overloads in family members, particularly mothers ${ }^{16}$. Carlsson et al. ${ }^{17}$ detected stress-related illnesses in some parents. Compared to parents of children with typical development, parents of children with ASD report poorer subjective wellbeing and increased physiological stress ${ }^{18}$, with studies in this field showing that this is greater in the mothers than in the fathers ${ }^{19}$.

In her narrative, $\mathrm{M} 11$ revealed stress and an intolerable burden due to her child's hyperactivity, a common comorbidity of ASD $^{20}$ that accounts for a poorer prognosis ${ }^{2}$. A study conducted with the same base population suggested that mothers of children with milder symptoms tend to emphasize their child's positive characteristics and to have more hope for their child's future compared to the mothers of children with more severe symptoms ${ }^{21}$. Therefore, it is reasonable to suppose that children with more severe symptoms are a greater physical burden on their parents, rendering them less hopeful about the future.

In agreement with Blanche et al. ${ }^{22}$, most mothers in this study were their autistic child's principal caregivers. They spent almost all their time caring for their children, adapting their daily, professional and academic lives. Other studies ${ }^{14,21-23}$ have reported that the mothers of autistic children needed to change their lives to cope with their child's demands, preventing them from having time for anything else such as professional activities, and obliging those who were in paid employment to give up their jobs ${ }^{4}$. Marques and Dixe ${ }^{24}$ stressed that parents need more time for themselves in their routine; moreover, they require someone to take care of their children to give them a few days of respite. As shown in the present study, other studies ${ }^{9,14,25}$ have also referred to the importance of social support networks in helping families overcome the challenges imposed by autism.

In this study, some fathers adapted their work schedule to allow them to help. The presence of the father can produce a better balance in the household, reverberating positively on the dynamics of the family and consequently on the child. A study conducted with the same base population identified support from the fathers as being an important buffer against symptoms of depression and anxiety in the mothers of autistic children with more severe behavioral symptoms ${ }^{9}$. Nevertheless, Favero-Nunes and Santos ${ }^{4}$ reported that most of the mothers complained that they were unable to count on their husband to help with routine tasks and the care of their child.

This study showed that having an autistic child is detrimental to the couple's relationship, in certain situations contributing to a marital crisis or separation. Serra ${ }^{23}$ also described a decrease in sexual desire among couples and the difficulty involved in securing moments of privacy, with $72 \%$ of participants having separated from their spouses following a diagnosis of ASD. Favero-Nunes and Santos ${ }^{4}$ reported tensions and conjugal conflicts resulting from the variety of functions that had to be performed when parenting an autistic child.

Mothers, in particular, reported that their social life had deteriorated because of their autistic child. They avoided going out with their children because of social discrimination and embarrassment. Consequently, they tended to isolate themselves. Smeha and Cesar ${ }^{14}$ reported changes in mothers' social and affective relationships as a consequence of having to care for their autistic child. Other studies ${ }^{26,27}$ have also reported discrimination and embarrassment in public places, resulting in restrictions to families' social lives and isolation when a member of the family has ASD 22,28 . Therefore, the discomfort of having their children's behavior judged by others led parents to break off certain social relationships ${ }^{29}$.

The fact that this study was conducted in only one site made it difficult for different/contradictory experiences to come to light, and it is considered a limitation. Future studies should include more varied samples insofar as experiences are concerned. Studies should include more than one institution and samples should include participants from different social classes to allow for a greater variety in the data collected. 


\section{CONCLUSIONS}

The condition of parenting an autistic child constitutes a problem that merits greater attention from healthcare professionals, particularly those working with mental health. Care strategies need to be implemented with the parents in addition to their child's healthcare to enable children with ASD and their families to be managed more effectively.

The results of the present study should be useful for healthcare professionals who care for children with ASD, keeping the parents' need for care in mind and also taking into consideration the important contribution to be made by providing social and professional support to help deal with demands.

\section{INDIVIDUAL CONTRIBUTIONS}

Milena Pereira Pondé - Was the researcher advisor and contributed substantially in the conception and design of the study, critically reviewed the intellectual content of this manuscript and approved its final version for publishing.

Márcia Cristina Maciel de Aguiar - Contributed substantially in the conception and design of the study, analyzed and interpreted the data, wrote the manuscript, and approved its final version for publishing.

\section{DISCLOSURE STATEMENT}

The authors have no financial relationships to disclose.

\section{ACKNOWLEDGEMENTS}

The authors are grateful to all participants.

\section{REFERENCES}

1. American Psychiatric Association (APA). Diagnostic and Statistical Manual of Mental Disorders. 5th ed. Arlington, VA: American Psychiatric Publishing; 2013.

2. Novaes CM, Pondé MP, Freire AC. Control of psychomotor agitation and aggressive behavior in patients with autistic disorder: a retrospective chart review. Arq Neuropsiquiatr. 2008;66(3b):646-51.

3. Darghouth S, Pedersen D, Bibeau G. Painful languages of the body: experiences of headache among women in two Peruvian communities. Cult Med Psychiatry. 2006;30(3):271-97.

4. Favero-Nunes MA, Santos MA. Itinerário Terapêutico Percorrido por Mães de Crianças com Transtorno Autístico. Psicol Reflex Crit. 2010;23(2):208-21.
5. Karst JS, Hecke AVV. Parent and Family Impact of Autism Spectrum Disorders: A Review and Proposed Model for Intervention Evaluation. Clin Child Fam Psychol Rev. 2012;15(3):247-77.

6. Almansour MA, Alateeg MA, Alzahrani MK, Algeffari MA, Alhomaidan HT. Depression and anxiety among parents and caregivers of autistic spectral disorder children. Neurosciences (Riyadh). 2013;18(1):58-63

7. Ou WX, Cha CH, Wang LH. [Mental health state of parents of children with autism]. Zhongguo Dang Dai Er Ke Za Zhi. 2010;12(12):947-49.

8. Estes A, Olson E, Sullivan K, Greenson J, Winter J, Dawson G, et al. Parenting-related stress and psychological distress in mothers of toddlers with autism spectrum disorders. Brain Dev. 2013;35(2):133-8

9. Machado Junior SB, Celestino MI, Serra JP, Caron J, Pondé MP. Risk and protective faCtors for symptoms of anxiety and depression in parents of children with autism spectrum disorder. Dev Neurorehabil. 2016;19(3):146-53.

10. Gibbs GR. Analysing qualitative data. London: Sage; 2008

11. Pondé MP, Mendonça MS, Caroso C. Proposta metodológica para análise de dados qualitativos em dois níveis. Hist Cienc Saude-Manguinhos. 2009;16(1):129-43.

12. Creswell J. Qualitative inquiry and research design: choosing among five approaches. Los Angeles: Sage; 2013

13. Brasil. Conselho Nacional de Saúde. Resolução no 466/12. Brasília: Ministério da Saúde; 2012.

14. Smeha LC, Cezar PK. A vivência da maternidade de mães de crianças com autismo. Psicol Estud. 2011;16(1):43-50.

15. Lim KK, Chong WH. Moderating effect of child's autism spectrum disorder (ASD) diagnosis on benefit finding and negative affect of parents. Am J Orthopsychiatry. 2017;87(3):357-64.

16. Gomes PT, Lima LH, Bueno MK, Araújo LA, Souza NM. Autism in Brazil: a systematic review of family challenges and coping strategies. J Pediatr (Rio J). 2015;91(1):111-21.

17. Carlsson E, Miniscalco C, Kadesjö B, Laakso K. Negotiating knowledge: parents' experience of the neuropsychiatric diagnostic process for children with autism. Int J Lang Commun Disord. 2016;51(3):328-38.

18. Costa AP, Steffsen G, Ferring D. Contributors to well-being and stress in parents of children with autism spectrum disorder. Res Autism Spectr Disord. 2017;37:61-72.

19. Bendixen RM, Elder JH, Donaldson S, Kairalla JA, Valcante G, Ferdig RE. Effects of a Fatherbased In-Home Intervention on Perceived Stress and Family Dynamics in Parents of Children with Autism. Am J Occup Ther. 2011;65(6):679-87.

20. Pondé MP, Novaes CM, Losapio MF. Frequency of symptoms of attention deficit and hyperactivity disorder in autistic children. Arq Neuropsiquiatr. 2010;68(1):103-6.

21. Celestino MI, Pondé MP, Iriart JA, Machado Jr SB, Serra JP. Perceptions, meanings and practices of mothers of children diagnosed with autism. Braz J Med Hum Health. 2013;1:165-8.

22. Blanche El, Diaz J, Barretto T, Cermak SA. Caregiving experiences of Latino families with children with Autism Spectrum Disorder. Am J Occup Ther. 2015;69(5):6905185010p1-11.

23. Serra D. Autismo, família e inclusão. Polêmica. 2010;9:40-56.

24. Marques MH, Dixe MA. Crianças e jovens autistas: impacto na dinâmica familiar e pessoal de seus pais. Rev Psiquiatr Clín. 2011;38(2):66-70.

25. Zanatta EA, Menegazzo E, Guimarães AN, Ferraz L, Motta MGC. Cotidiano de famílias que convivem com 0 autismo infantil. Rev Baiana Enferm. 2014;28(3):271-82.

26. Silva EBA, Ribeiro MFM. Aprendendo a ser mãe de uma criança autista. Estudos. 2012;39(4):579-89.

27. Filho ALMM, Nogueira LANM, Silva KCO, Santiago RF. A importância da família no cuidado da criança autista. Rev Saúde em Foc0. 2016;3(1):66-83.

28. Segeren L, Françozo MFC. As vivências de mães de jovens autistas. Psicol Estud. 2014;19(1):39-46

29. Silva RS, Chaves EF. Autismo, reações e consequências nas relações familiares. Encontro Rev Psicol. 2014;17(26):35-45. 